\title{
Anadolu Arısı Ege Ekotipi (Apis mellifera anatoliaca) ve İtalyan (Apis mellifera ligustica) X Ege Melezi Bal Arılarının ve Farklı Yüksük Sayılarının Arı Sütü Verimleri Üzerine Etkileri
}

\author{
Ahmet ERDOĞAN ${ }^{1}$, Aytül UÇAK KOÇ ${ }^{*}$, Mete KARACAOĞLU ${ }^{3}$ \\ ${ }^{1}$ Adnan Menderes Üniversitesi, Fen Bilimleri Enstitüsü, Aydın \\ ${ }^{2}$ Adnan Menderes Üniversitesi, Koçarlı MYO, Aydın \\ ${ }^{3}$ Adnan Menderes Üniversitesi, Ziraat Fakültesi, Zootekni Bölümü, Aydın \\ *Sorumlu Yazar: aucak@adu.edu.tr
}

Öz

Araştırma, Ege Bölgesi koşullarında beş dönemde, Anadolu arısı Ege ekotipi ve İtalyan X Ege melez gruplarında, farklı sayıda (150 ve 200 adet) larva aktarmanın arı sütü verimi üzerine etkilerini belirlemek amacıyla yapılmıştır. Araştırma sonuçlarına göre, Ege ekotipi kolonileri ile İtalyan X Ege melezi koloniler sırası ile larva kabul oranı (\%71.1 \pm 2.72 ve $\% 70.6 \pm 2.23)$, ve bir koloniden elde edilen toplam arı sütü verimi $(28.5 \pm 2.70 \mathrm{~g}$ ve $26.7 \pm 4.60 \mathrm{~g})$ bakımından benzer, bir yüksükteki arı sütü verimi bakımından $(229 \pm 8.9 \mathrm{mg}$ ve $216 \pm 10.2 \mathrm{mg}$ ) farklı bulunmuştur $(\mathrm{P}<0.05)$. Farklı sayıda (150 ve 200 adet) larva aşılamanın larva kabul oranı ve bir yüksükteki arı sütü verimi üzerine etkisi önemli bulunmuştur ( $\mathrm{P}<0.05)$. Araştırmada, aşılanan yüksük sayısı artıkça larva kabul oranının düştüğü ancak kolonilerin toplam arı sütü üretimlerinin arttığı saptanmıştır. Bu çalışmanın sonuçları, Ege ekotipinin arı sütü üretiminde değerlendirilme olanağının bulunduğunu göstermektedir.

Anahtar Kelimeler: Anadolu arısı Ege ekotipi (Apis mellifera anatoliaca), Arı sütü üretimi, İtalyan arısı (Apis mellifera ligustica), Yüksük sayısı

\section{Effects of Aegean Ecotype (Apis mellifera anatoliaca) and Italian (Apis mellifera ligustica) x Aegean Crossbred Honeybee Colonies and Number of Grafted Larvae on Royal Jelly Production}

\begin{abstract}
This research was conducted to determine the effects of Aegean ecotypes of Anatolian (A. m. anatoliaca) and Italian ( $A$. $m$. ligustica) x Aegean crossbred honeybee colonies on the royal jelly production in the conditions of South Aegean region. In addition to that of the effects of number of grafted larvae on royal jelly production was also determined. The average acceptance rate $(71.1 \pm 2.72 \%$ and $70.6 \pm 2.23 \%)$, and total colony yields of royal jelly $(28.5 \pm 2.70 \mathrm{~g}$ and $26.7 \pm 4.6 \mathrm{~g})$ were found similar, but amount of royal jelly in per cell $(229 \pm 8.9 \mathrm{mg}$ and $216 \pm 10.2 \mathrm{mg}$ ) were found significant $(P<0.05)$ in Aegean ecotypes and Italian $x$ Aegean crossbred honeybees, respectively. The differences between the colonies for the number of grafted larvae, the average acceptance rate, amount of royal jelly in per cell were found significant $(P<0.05)$. As the number of grafted larvae increased, the rate of acceptance of colonies decreased, but the total royal jelly production of colonies were increased. Aegean ecotype was found to be suitable for royal jelly production under the conditions of South Aegean region.
\end{abstract}

Key Words: Aegean ecotype of Anatolian honey bee (Apis mellifera anatoliaca), Italian honey bee (Apis mellifera ligustica), Royal jelly production, Number of grafted larvae. 


\section{Giriş}

Arı sütü, arı kolonisinin en önemli ürünlerinden birisidir. Arı sütü, 5-15 günlük yaşta genç işçi arıların yan yutak ve üst çene bezlerinden salgılanır, kolonide ana arının tüm yaşamı süresince, işçi ve erkek arıların genç larva dönemi beslenmesinde kullanılır. Arı sütü krem renginde yapışkan bir yapıda olup ekşi tadı vardır. Arı sütünün kompozisyonu, arıların beslenmesine, mevsime ve larvanın yaşına göre değişmektedir. Suda eriyen, $\mathrm{pH}^{\prime}$ sı $3.4-4.5$ olan arı sütünün yapısında; su (\% 60-70), protein (\% 9-18), lipit (\% 3-8), karbonhidrat (\% 7-18), kül (\% 0.8-3), 10-Hidroksi-2-Dekenoik Asit (>\%1.4) içermektedir (Sabatini ve ark., 2009).

Arı sütünün bal arılarında gösterdiği etkiye benzer etkilerin insanlarda da göstereceğine inanılır. Bu nedenle arı sütü, diyetlerin düzenlenmesi ve kozmetik endüstrisinde en önemli fonksiyonel ürünlerden biridir. Arı sütünün insanlarda ve hayvanlarda farmakolojik etkileri konusunda çalışmalar yapılmıştır. Arı sütü, iç salgı sistemini düzenleyen, bağışıklık mekanizmasını geliştiren, strese karşı, kolesterol düşürücü, yaşlanmaya ve iltihaplanmaya karşı, damarlanmayı önleyici, yaraları iyileştirici antibiyotik etkileri olan arı ürünüdür (Chen ve ark.,2002; Kohno, 2004; Temamoğulları ve ark., 2006; El Nekeety ve ark., 2007; Kanbur ve ark., 2009; Mannoor ve ark., 2009; Cavuşoğlu, 2009; Ramadana ve Ghamdi, 2012; Wytrychowski ve ark., 2013; Wang ve ark., 2015; Xin ve ark., 2016).

Kolonilerin arı sütü verimi, genotip başta olmak üzere, nektar ve polen kaynaklarının yoğunluğu, mevsim, üretim yöntemi, koloni gücü ve yavru alanı, polen ve şeker şurubu ile besleme yapılıp yapılmadığı, başlatıcı kolonilerin ana arılı ya da ana arısız olup olmaması, aşılanan yüksük sayısı ve larva kabul oranı, hasat zamanı gibi faktörlere bağlıdır (Jianke ve Weitua, 1995; Kutluca ve ark., 1998; Şahinler ve Şahinler, 2002; Şahinler ve Kaftanoğlu, 2005; Zheng ve ark., 2011; Kösoğlu ve ark., 2013).

Türkiye, bulunduğu coğrafya, sahip olduğu bitki çeşitliliği ve uygun iklim koşulları ile önemli bir arıcılık ülkesidir. FAO 2013 verilerine göre, ülkede 6 milyon 348 bin kolonide 95 bin ton bal üretilmiştir. Ancak arı kolonisinin en önemli arıcılık ürünlerinden biri olan arı sütü üretimi yok denecek kadar azdır. Oysa 8 milyon koloniye sahip Çin, kesin veriler olmamakla birlikte tahminen yılda 2000 ton arı sütü üretmekte, tamamına yakınını Japonya, ABD ve Avrupa'ya satmaktadır (Sabatini ve ark.,2009).

Anadolu coğrafyasının bal arısının anavatanının bir parçası olması, farklı ekolojik koşulları, arıcılı̆ı̆ en yaygın ve geleneksel tarımsal faaliyetlerin başında gelmesi, bal arısı ırk ve ekotiplerinin genetik çeşitliliğine olanak sağlamıştır. Anadoluda, morfolojik ve davranış özellikleri birbirinden farklı ekotipleri içeren en geniş bal arısı kitlesini Anadolu arısı (Apis mellifera anatoliaca) oluşturmaktadır (Doğaroğlu ve ark.,1992; Karacaoğlu ve Fıratlı, 1998; Genç ve ark., 1999; Gençer ve Fıratlı, 1999; Güler ve Kaftanoğlu, 1999). Anadolu arısının Batı Anadolu'da Muğla arısı da denilen Ege ekotipi yetiştirilmektedir. Ege ekotipi üzerinde yapılan çalışmalarda, ekotipin farklı morfolojik yapı ve üreme düzeni ile diğer ekotiplerden ayrıldığı, daha yüksek üreme aktivitesi gösterdiği ve daha fazla bal ürettiği ortaya konmuştur (Doğaroğlu ve ark.,1992; Kaftanoğlu ve ark., 1993; Güler ve Kaftanoğlu, 1999; Güler ve ark., 1999; Karacaoğlu ve Uçak, 2003; Gençer ve Karacaoğlu, 2003; Karacaoğlu, 2005; Uçak ve Karacaoğlu, 2005 ; Akyol ve ark., 2005; 
Uçak Koç ve Karacaoğlu, 2011; Yücel ve Kösoğlu, 2011; Akyol ve ark., 2014.)

Koloninin populasyon düzeyi, arı sütü verimini etkilemektedir. Bu nedenle yavru yetiştirme etkinliği yüksek genotiplerin daha fazla arı sütü üretebileceklerini söylemek olasıdır. Ülkemizde arı sütü üretiminin ve verimliliğin artması; kullanılan materyalin seçiminden başlayarak bir dizi uygulamanın doğru yapılması ile olanaklıdır. Anadoluda çeşitli arı ekotiplerinin; morfolojik, fizyolojik ve davranış özelliklerinin incelendiği araştırmalarda ortak bulgu, Ege ekotipinin diğer ekotiplerden farklı, yavru yetiştirme etkinliği yüksek ve bal veriminin fazla olduğudur (Karacaoğlu ve ark., 2004). Bu araştırma, ülke arııılığı içinde önemli yeri olan Anadolu arısı Ege ekotipi ile Aydın yöresinde doğal çiftleşmiş İtalyan ana arılı kolonilerin arı sütü verim potansiyellerinin ortaya konulması amacıyla yapılmıştır.

\section{Materyal ve Metot}

Araştırma, Adnan Menderes Üniversitesi Ziraat Fakültesi Arılığında yürütülmüştür. Genotip gruplarından Anadolu arısı Ege Ekotipi (E) kolonileri, önceki yıllarda ADÜ Ziraat Fakültesinde kurulan damızlık Ege arısı sürüsünden yetiştirilen ana arılar ile İtalyan (i) kolonileri ise, İsrail'de "Tsrifin Bee Research Center" adlı Araştırma Merkezinden getirilen damızlık İtalyan kolonilerinden yetiştirilen ana arılar ile oluşturulmuştur.

Denemenin ilk yılında, mayıs ayında larva aktarım yöntemi ile damızlık $E$ ve i kolonilerinden 12'şer adet ana arı yetiştirilmiş, doğal çiftleşmeye bırakılmıştır. Yumurtlamaya başladıklarında $1.5 \mathrm{~kg}$ arı silkilmiş paket kolonilere verilmiştir. Deneme desenine uygun olarak oluşturulan paket kolonileri, gerekli bakım beslemesi yapılarak kışlatılmışlardır. Denemenin ikinci yılında, erken ilkbahar döneminde deneme kolonileri arı populasyonu bakımından güçlendikten sonra arı sütü üretimi için hazır hale gelmiştir. Arı sütü üretimi mayıs ayında, 5 dönemde gerçekleşmiştir. Her dönemde (her hafta) 2 adet $E$ ve 2 adet $I$ x E üretim kolonisine 150 ve 200 adet larva olacak şekilde toplam 700 adet larva aktarımı yapılmıştır (Laidlaw, 1985). Larva aktarımı yapıldıktan sonra aşılama çerçeveleri ana arısız deneme kolonilerine verilmiştir.

Arı sütü üretiminde hasat genellikle larva aktarımı yapıldıktan 72 saat sonra yapılmaktadır. Ancak larva aktarıldıktan 24, 48 ve 72 saat sonra yapılan hasadın arı sütü miktar ve nitelikleri üzerinde etkili olduğu bildirilmektedir (Zheng ve ark., 2011; Kösoğlu ve ark., 2013). Bu çalışmada, larva aktarımından 72 saat sonra hasat yapılmıştır. Üretim kolonilerinde önce kabul edilen yüksükler sayılmış, larva kabul oranı belirlenmiştir. Yüksüklerin boyları bir bıçak yardımıyla arı sütü hizasına kadar kısaltılarak larvalar bir pens yardımıyla alınmış, arı sütü, özel olarak düzenlenmiş vakum pompası ile yüksüklerden toplanmıştır. Her üretim kolonisinden toplanan arı sütü tartılarak arı sütü verimi belirlenmiştir. Bir yüksükteki ortalama arı sütü miktarı, toplam arı sütü miktarının kabul edilen yüksük sayısına bölünmesi sonucunda elde edilmiştir. Araştırma verilerinin istatistik analizinde SAS (1999) paket programı kullanıımıştır. Ortalamalar arasındaki farklılıkların belirlenmesi amacıyla Tukey çoklu karşılaştırma testi yapılmıştır $(P<0.05)$.

\section{Araştırma Bulguları ve Tartışma}

Ege ve İtalyan x Ege melezi, 150 ve 200 adet larva aktarımı yapılan kolonilerde; beş dönemde larva kabul oranı, bir yüksükteki arı sütü miktarı ve toplam arı sütü verimine ilişkin veriler Çizelge 1 ve Çizelge 2'de özetlenmiştir. 


\section{Larva kabul oranı}

Araştırmada elde edilen verilere uygulanan varyans analizinde dönemler $(P<0.01)$ ve yüksük sayısı farkları önemli $(P<0.05)$, genotipler arası fark önemsiz bulunmuştur. Dönemlere göre larva kabul oranı sırasıyla; $\% 60.5, \% 78.1, \% 80.2, \% 66.6$, \% 69.4 olarak saptanmıştır (Çizelge 1.). En yüksek larva kabul oranı üçüncü dönemde elde edilmiş, bu dönem ikinci döneme benzer diğer dönemlerden farklı $\quad(P<0.05)$ bulunmuştur. Her iki genotipte de aktarılan larva sayısı, larva kabul oranını etkilemiştir. Ege genotipinde larva aktarılan 200 adet yüksükten beş dönem boyunca ortalama \% $68.2 \pm 2.51^{\prime}$ ü, larva aktarılan 150 adet yüksükten beş dönem boyunca ortalama \% 73.6 62.24 'ü kabul edilmiştir (Çizelge 1). Genel olarak İtalyan melezi kolonilerde de benzer değerler elde edilmiştir. Larva kabul oranı bakımından genotip*yüksük sayısı interaksiyonu önemsiz bulunmuştur.

\section{Arı sütü verimi}

Bir yüksükteki arı sütü miktarı, her bir kolonide toplam arı sütü üretiminin kabul edilen larva sayısına bölünmesi sonucu elde edilmiştir. Yapılan varyans analizinde, dönemler, genotip ve yüksük sayısı farkları önemli $(P<0.05)$ bulunmuştur. Dönemlere göre en fazla arı sütü verimi, birinci dönemde $(283 \pm 30.4 \mathrm{mg})$ elde edilmiş, 1 . dönem 3 . döneme benzer, diğer dönemlerden farklı $(P<0.05)$ bulunmuştur (Çizelge 1$)$. Ege genotipinde 5 dönem ortalaması $(229 \pm 8.9$ $\mathrm{mg}$ ) italyan melezinden $(216 \pm 10.2 \mathrm{mg})$ farklı bulunmuştur $(P<0.05)$. Arı sütü verimi bakımından, 150 adet larva aktarılan koloniler (ortalama $248 \pm 15.9 \mathrm{mg}$ ) 200 adet larva aktarılan kolonilerden (ortalama 198 \pm 22.5 $\mathrm{mg}$ ) farklı $(\mathrm{P}<0.05)$, bulunmuştur (Çizelge 2 ).

\section{Toplam arı sütü verimi}

Araştırmada, varyans analizi sonuçlarına göre; genotip, yüksük sayısı farkları ve genotip*yüksük sayısı interaksiyonu önemsiz, dönemler arası farklar önemli $\quad(P<0.05)$ bulunmuştur. En çok arı sütü 3. dönemde (18 Mayıs) üretilmiş (34.0 $02.5 \mathrm{~g}$ ), bu dönem 1 ve 2. dönemlere benzer 4 . ve 5 . dönemlerden farklı olmuştur (Çizelge 1). Ege genotipinde ortalama $28.5 \pm 2.70 \mathrm{~g}$, Italyan melezinde ortalama $26.7 \pm 4.60 \mathrm{~g}$ hasat edilmiştir. Arı sütü verimi, 150 adet larva aktarılan kolonilerde ortalama $26.6 \pm 4.04 \mathrm{~g}, 200$ larva aktarılan kolonilerde ortalama $28.1 \pm 5.60 \mathrm{~g}$ olarak belirlenmiştir (Çizelge 2).

Araştırma, Ege Bölgesi (Aydın) koşullarında, Ege ve Italyan x Ege melezi genotiplerde beş dönemde yapılmıştır. Larva kabul oranı bakımından genotipler benzer, yüksük sayıları farklı bulunmuştur. Bir yüksükteki arı sütü verimi bakımından dönemler, yüksük sayıları ve genotipler arasındaki farklar ise önemli bulunmuştur. Koloni ortama arı sütü verimleri bakımından genotipler ve yüksük sayıları benzer bulunmuştur. Arı sütü verimi ve larva tutma oranı üzerinde genotip başta olmak üzere, nektar ve polen kaynaklarının yoğunluğu, mevsim, koloni gücü, aktarılan larva sayısı gibi faktörler etkilidir. Araştırmanın yapııdığı Ege Bölgesinde ana arı ve arı sütü üretimine mart ayının ikinci yarısında başlanabilir (Uçak ve Karacaoğlu, 2004; Karacaoğlu ve ark., 2004; Karacaoğlu ve Uçak Koç, 2009). 
Çizelge 1. Dönemlerde kolonilerin tutma oranı (\%) bir yüksükteki arı sütü miktarı (mg) ve her dönemde bir koloniden hasat edilen arı sütü verimi (g)

Table 1. The acceptance rates (\%) and royal jelly per cell ( $\mathrm{mg}$ ) and average colony yield per harvest production $(\mathrm{g})$ in different weeks in colonies $(\mathrm{g})$

\begin{tabular}{|c|c|c|c|c|c|c|c|c|}
\hline & $\begin{array}{l}\text { Genotip } \\
\text { Genotype }\end{array}$ & $\begin{array}{c}\text { Yüksük } \\
\text { sayısı } \\
\text { Number } \\
\text { of cell }\end{array}$ & $\begin{array}{c}1 . \\
\text { Dönem } \\
\text { Period }\end{array}$ & $\begin{array}{c}2 . \\
\text { Dönem } \\
\text { Period } \\
\end{array}$ & $\begin{array}{c}3 . \\
\text { Dönem } \\
\text { Period }\end{array}$ & $\begin{array}{c}4 . \\
\text { Dönem } \\
\text { Period } \\
\end{array}$ & $\begin{array}{c}5 . \\
\text { Dönem } \\
\text { Period }\end{array}$ & $\begin{array}{c}\text { Ort. } \\
\text { Average }\end{array}$ \\
\hline \multirow{5}{*}{ 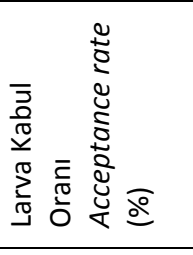 } & $E$ & 150 & $65 \pm 3.5$ & $72 \pm 2.2$ & $84.5 \pm 2.2$ & $75.5 \pm 2$. & $70.5 \pm 2.0$ & $73.6 \pm 2.24$ \\
\hline & $E$ & 200 & $56 \pm 3.5$ & $80 \pm 3.5$ & $81.3 \pm 3.5$ & $59.3 \pm 3$ & $65.3 \pm 3.5$ & $68.2 \pm 2.51$ \\
\hline & İxE & 150 & $65 \pm 2.2$ & $80 \pm 2.2$ & $79.5 \pm 2.2$ & $71 \pm 2.2$ & $69.0 \pm 2.0$ & $73.0 \pm 2.05$ \\
\hline & İxE & 200 & $55 \pm 3.3$ & $80 \pm 3.2$ & $75 \pm 3.3$ & $60 \pm 3.2$ & $72.0 \pm 3.3$ & $68.0 \pm 3.23$ \\
\hline & Ort. & & $60.5 \pm 2.1^{c}$ & $78.1 \pm 1.2^{\mathrm{ab}}$ & $80.2 \pm 1.8^{a}$ & $66.6 \pm 2.5^{c}$ & $69.4 \pm 2.6^{\mathrm{bc}}$ & $69.6 \pm 2.14$ \\
\hline \multirow{5}{*}{ 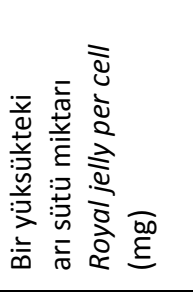 } & $\mathrm{E}$ & 150 & $248 \pm 15.9$ & $251 \pm 15.9$ & $306 \pm 15.9$ & $208 \pm 15.9$ & $183 \pm 15.9$ & $239 \pm 15.9$ \\
\hline & $\mathrm{E}$ & 200 & $210 \pm 2.5$ & $231 \pm 2.5$ & $279 \pm 2.5$ & $202 \pm 2.5$ & $168 \pm 2.5$ & $218 \pm 2.5$ \\
\hline & İxE & 150 & $377 \pm 10.0$ & $246 \pm 10.0$ & $236 \pm 10.0$ & $152 \pm 10.0$ & $268 \pm 10.0$ & $256 \pm 10.0$ \\
\hline & İxE & 200 & $295 \pm 22.5$ & $148 \pm 22.5$ & $155 \pm 22.5$ & $151 \pm 8.5$ & $138 \pm 22.5$ & $177 \pm 22.5$ \\
\hline & Ort. & & $283 \pm 30.4^{\mathrm{a}}$ & $219 \pm 3.6^{b}$ & $244 \pm 3.6^{\mathrm{ab}}$ & $178 \pm 3.6^{c}$ & $189 \pm 3.6 b c$ & $219 \pm 3.60$ \\
\hline \multirow{5}{*}{ 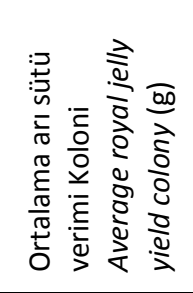 } & $E$ & 150 & $20.5 \pm 3.9$ & $30.2 \pm 3.9$ & $37.3 \pm 3.9$ & $18.6 \pm 3.9$ & $17.9 \pm 3.9$ & $24.9 \pm 3.9$ \\
\hline & $E$ & 200 & $27.4 \pm 1.9$ & $33.4 \pm 1.9$ & $47.2 \pm 1.9$ & $30.52 \pm 1.9$ & $23.7 \pm 1.9$ & $32.4 \pm 1.9$ \\
\hline & İxE & 150 & $31.7 \pm 5.6$ & $29.5 \pm 5.6$ & $26.6 \pm 5.6$ & $13.8 \pm 5.6$ & $29.0 \pm 5.6$ & $26.1 \pm 5.6$ \\
\hline & İxE & 200 & $38.4 \pm 4.4$ & $23.9 \pm 4.4$ & $24.6 \pm 4.4$ & $21.1 \pm 4.4$ & $19.4 \pm 4.4$ & $23.4 \pm 4.4$ \\
\hline & Ort. & & $29.5 \pm 2.5^{\mathrm{ab}}$ & $29.2 \pm 2.5^{\mathrm{ab}}$ & $34.0 \pm 2.5^{a}$ & $21.0 \pm 2.5^{c}$ & $22.5 \pm 2.5^{c}$ & $26.73 \pm 2.5$ \\
\hline
\end{tabular}

Çizelge 2. Genotip ve yüksük sayıları larva kabul oranı (\%) bir yüksükteki arı sütü verimi (mg) ve koloni verimi ( $\mathrm{g}$ ) ortalamaları

Table 2 . The acceptance rates $(\%)$ and royal jelly per cell $(\mathrm{mg})$ and average colony yield per harvest production $(\mathrm{g})$ in colonies.

\begin{tabular}{|c|c|c|c|c|c|}
\hline $\begin{array}{l}\text { Gruplar } \\
\text { Groups }\end{array}$ & $\begin{array}{l}\text { Koloni sayısı } \\
\text { Colony number }\end{array}$ & $\begin{array}{l}\text { Yüksük sayısı } \\
\text { Cell number }\end{array}$ & $\begin{array}{c}\text { Tutma oranı } \\
\text { Acceptance rates } \\
(\%)\end{array}$ & $\begin{array}{l}\text { Bir yüksükteki arı } \\
\text { sütü verimi } \\
\text { Royal jelly yield } \\
\text { per cell (mg) }\end{array}$ & $\begin{array}{c}\text { Ort. koloni } \\
\text { verimi } \\
\text { Ave. colony yield } \\
\text { (g) }\end{array}$ \\
\hline \multicolumn{6}{|l|}{ Genotip } \\
\hline Ege & 10 & 1750 & $71.1 \pm 2.72^{\mathrm{a}}$ & $229 \pm 8.9^{a}$ & $28.5 \pm 2.70^{\mathrm{a}}$ \\
\hline İtalyanXEge & 10 & 1750 & $70.6 \pm 2.23^{a}$ & $216 \pm 10.2^{b}$ & $26.7 \pm 4.60^{a}$ \\
\hline Ortalama & 20 & 3500 & $70.8 \pm 2.17$ & $222 \pm 6.9$ & $27.6 \pm 4.32$ \\
\hline \multicolumn{6}{|l|}{ Yüksük sayısı } \\
\hline 150 & 10 & 1500 & $73.6 \pm 2.24^{a}$ & $248 \pm 15.9^{a}$ & $26.6 \pm 4.04^{a}$ \\
\hline 200 & 10 & 2000 & $68.1 \pm 2.17^{b}$ & $198 \pm 22.5^{b}$ & $28.1 \pm 5.60^{a}$ \\
\hline Ortalama & 20 & 3500 & $70.7 \pm 2.21$ & $222 \pm 6.9$ & $27.6 \pm 4.30$ \\
\hline
\end{tabular}


Ancak bu çalışmada, kolonilerin arı sütü üretimi için öngörülen güce ulaşmaları nisan sonunda mümkün olmuş, bu nedenle arı sütü üretimine mayıs ayında başlanmıştır. Yörede, mayıs ayının ikinci yarısında nektar ve polen kaynaklarının azalması kolonilerin arı sütü veriminde azalmaya sebep olmuştur. Konu ile ilgili araştırmalarda; genotipler, ekolojik koşullar, mevsim ve aktarılan larva sayılarının farklı olması araştırmanın sonuçlarını önceki çalışmalarla karşılaştırıımasını güçleştirmektedir. Bu çalışmada elde edilen larva kabul oranı, bir yüksükteki arı sütü verimi, Türkiye'de ve yurt dışında yapılan önceki çalışmalardan bir kısmı ile benzer (Shengming ve ark., 1993, Shibi ve ark., 1993; Karacaoğlu ve ark., 2004), bir kısmından farklı (Jianke ve Weitua, 1995, Kutluca ve ark., 1998; Jianke, 1995; Şahinler ve Şahinler, 2002; Chen ve ark.,2002; Şahinler ve Kaftanoğlu, 2005; Şahinler ve ark., 2005; Zheng ve ark., 2011; Kösoğlu ve ark., 2013) bulunmuştur. Araştırmada ticari arı sütü üretiminde olduğu gibi her bir koloni için 150 ve 200 'şer adet larva aktarımı yapılmış, bu nedenle larva kabul oranı ve bir yüksükteki arı sütü miktarları genellikle düşük bulunmuştur.

\section{Sonuçlar}

Arı sütü üretimi daha çok saf İtalyan arıları ile yapılmakta, diğer ırk ve ekotiplerin bu ırkın verim düzeyine ulaşamadığı bildirilmektedir (Shibi ve ark., 1993; Chen ve ark., 2002). Ancak bu çalışmada belirlenen sonuçlara göre, Anadolu arısı (A. m. anatoliaca) Ege ekotipinin arı sütü üretimi bakımından Italyan ana arılı kolonilerden istatistik olarak önemli olmasa da bir miktar daha fazla arı sütü üretmiştir. Bu çalışma sonuçlarına göre Ege ekotipinin arı sütü üretimi bakımından İtalyan arısına benzer değerler göstermesi çoğunlukla bal ve polen üretimine yönelik çalışan bölge arııılarının, bu genotipi arı sütü üretiminde de değerlendirme olanağının bulunduğu söylenebilir.

\section{Ekler}

Bu çalışmanın gerçekleşmesi için finansal destek sağlayan Bilimsel Araştırma Projeleri Komisyon Başkanlığı'na desteği için teşekkür ederiz.

Bu makale Yüksek Lisans çalışmasından özetlenmiştir.

\section{Kaynaklar}

Akyol, E., Özkök, D., Öztürk, C., Bayram, A., 2005. Bazı saf ve melez balarısı (Apis mellifera $\mathrm{L}$.) kolonilerinin oğul eğilimi, yaşama gücü, kışlama yeteneği ve petek işleme etkinliklerinin belirlenmesi üzerine bir araştırma, Uludağ Arıcılık Dergisi Kasım 5: 162-166.

Akyol, E., Ünalan, A., Yeninar, H., Özkök, D., Özturk, C., 2014. Comparison of colony performances of Anatolian, Caucasian and Carniolan honeybee (Apis mellifera L.) genotypes in temperate climate conditions. Italian Journal of Animal Science, 13(3): 637-640.

Chen $Q$, Koga $T$, Uchi H, Hara H, Terao H, Moroi $Y$, Urabe K, Furue M., 2002. Propionibacteriumacnes-induced IL-8 production may be mediated by NF-kappa $B$ activation in human monocytes. J. Dermatol. Sci., 29: 97-103

Cavuşoğlu, K., Yapar, K., Yalıın, E., 2009. Royaljelly (honeybee) is a potential antioxidant against cadmium-induced genotoxicity and oxidative stress in albino mice. J. Med. Food, 12: 1286-1292.

Doğaroğlu, M.,Özder, M., Polat, C., 1992. Türkiye'de önemli bal arısı (Apis mellifera L.) Irk ve ekotiplerinin Trakya koşullarında performanslarının karşılaştırılması. Doğa Tr. J. of Veterinary and Animal Sciences, 16:403-414.

El-Nekeety, A. A., W El-Kholy,W., Abbas N. F., Ebaid, A., Amra, H.A., Mosaad A.V., 2007. Efficacy of royal jelly against the oxidative stress of fumonisin in rats. Toxicon, 50(2): 256-269.

Genç, F., Dülger, C., Dodoloğlu, A., Kutluca, S., 1999. Kafkas Orta Anadolu ve Erzurum 
balarısı (Apis mellifera L.) genotiplerinin Erzurum koşullarındaki bazı fizyolojik özelliklerinin karşılaştırılması. Tr. J. Of Veterinary and Animal Sciences, 23 (1999) Ek sayı 4. 645- 650.

Gençer, H.V., Fıratlı, Ç., 1999. Orta Anadolu ekotipleri (A. m. anatoliaca) ve Kafkas ırkı (A. m. caucasica) bal arılarının morfolojik özellikleri. Tr. J. of Veterinary and AnimalSciences, 23(1): 107-113.

Gençer, H.V., Karacaoğlu, M., 2003. Kafkas ırkı (Apis mellifera caucasica) ve Kafkas ırkı ile Anadolu arısı-Ege ekotipi (Apis mellifera anatoliaca)'nin karşılıklı melezlerinin Ege bölgesi koşullarında yavru yetiştirme etkinlikleri ve bal verimleri. Yüzüncü $Y_{\imath} l$ Üniversitesi. Ziraat Fakültesi. Tarım Bilimleri Dergisi (J. Agric. Sci.), 13(1):61- 65.

Güler, A., Korkmaz, A., Kaftanoğlu, O., 1999. Reproductive characteristics of Turkish honeybee (Apis mellifera L.) genotypes. Hayvansal Üretim, 39-40:113-119.

Güler, A., Kaftanoğlu, O., 1999. Determination of performances some important races and ecotypes of Turkish honeybee (Apis mellifera L.) under migratory beekeeping conditions. Turkish Journal of Veterinary and Animal Sciences, 23(3): 577-5781.

Jianke, L., Weitua, Y., 1995. Interrelationship between number of queen cells and royal jelly quantity and quality. Apimondia Zhengzhou Animal Husbandry Engineering Collage Zhenghou 450045. China.

Kaftanoğlu, O., Kumova. U., Bek. Y., 1993. GAP Bölgesinde çeşitli bal arısı (Apis mellifera) ırklarının performanslarının saptanması ve bölgedeki mevcut arı ırklarının ıslahı olanakları. Ç.Ü. Ziraat Fakültesi Genel Yayın No: 74. Adana

Kanbur, M., Eraslan, G., Beyaz. L., Silici, S., Liman, B.C., Altınordulu, Ş., Atasever A., 2009. The effects of royal jelly on liver damage induced by paracetamol in mice. Experimental and Toxicologic. Pathology, 61(2): 123-132.

Karacaoğlu, M., Fıratlı, Ç., 1998. Bazı bal arısı ekotipleri (Apis mellifera anatoliaca) ve melezlerinin özellikleri: 1. Morfolojik özellikler. Tr. J. of Veterinary and Animal Sciences, 22 :17-21.

Karacaoğlu, M., Uçak, A., 2003. Güney Ege koşullarında farklı dönemlerde yetiştirilen ana arılar ile oluşturulan kolonilerin gelişimi. III. Ulusal Zootekni Kongresi, 14-16 Ekim 2002, s:181-189. Ankara.
Karacaoğlu, M., Kösoğlu, M., Uçak Koç A., 2004. Farklı yöntemlerin Ege ekotipi (A.m. anatoliaca) ve Kafkas (A. m. caucasica) $\mathrm{x}$ Ege melezi bal arılarının arı sütü verimleri üzerine etkileri. ADÜ Ziraat Fakültesi Dergisi, 1(1): 29-33.

Karacaoğlu, M., 2005. Anadolu arısı Ege ekotipi ( $A$. $m$. anatoliaca) ve italyan arısı (A. $m$. ligustica) X Ege ekotipi melezi arılarının morfolojik özellikleri. ADÜ Ziraat Fakültesi Dergisi, 1 (2):41-46.

Karacaoğlu, M., Uçak Koç, A., 2007. Ege Bölgesi arıcılığında kısıtlar ve fırsatlar. Ege Bölgesi Arıcılık Semineri, 15-16 Şubat 2007, Bildiriler Kitabı, s:25-32.

Kohno, K., Okamoto, I., Sano, O., 2004. Royal jelly inhibits the production of proinflammatory cytokines by activated macrophages. Biosci. Biotechnol. Biochem., 68:138-145.

Kösoğlu, M., Yücel, B., Gökbulut, C., Konak, R., Bircan, C., 2013. The effect of harvesting time on some biochemical and trace element compositions of royal jelly. Kafkas Üniversitesi Veteriner Fakültesi Dergisi, 19(2): 233-237.

Kutluca, S., Genç, F., Dodoloğlu, A., 1998. Besleyici kolonilere verilen ana arı yüksüklerinin sayısı ile hasat aralığının kolonilerin arısütü verimine etkisi. $\operatorname{Tr} J$ of Veterinary and Animal Sciences, 22:363-369.

Laidlaw, H. H. Jr., 1985. Contemporary Queen Rearing. Dadant Publication. Dadant and Sons, Hamilton, Illinois.

Mannoor, M.K., Shimabukuro, I., Tsukamotoa, M., Watanabe, H., Yamaguchi., K., Sato, Y., 2009. Honeybee royal jelly inhibits autoimmunity in SLE-prone NZB $\times$ NZW F1 mice. Lupus 18: 44-52.

Ramadana, M.F., Al-Ghamdi, A., 2012 Bioactive compounds and health-promoting properties of royal jelly: A review, Journal of Functional Foods, 4: $39-52$.

Sabatini, A.G., Marcazzan, G.L., Caboni, M.F., Bogdanov, S., de Almeida-Muradian, L.B., 2009. Quality and standardisation of royal jelly. Journal of Api Production Api Medical Science, 1. 1-6.

SAS, 1999. Statistical Analysis Sistem for Windows (Release 8.2). SAS Institutelnc., Raleigh, North Carolina, USA.

Shengming, H., Fuhai, L., Fuxiu, L., Shibi, C., 1993. Study on the relationship between royal jelly yield and supplementary feeding. China Pupular Science Press, Beijing-China, p.131-144. 
Shibi, C., Shengming, H., Fuahi, L., Puxiu, L., 1993. Studies on the relationship between the bee races and yield of royal jelly. Bee honey, Roya Jelly Environment. Edit. Dept. of Beekeeping Technology, Beelnst. CAAS, Beijing, China p.40-53.

Şahinler, N., Sahinler, S., 2002. Effects of the number of queen cells and harvesting interval on the acceptance rates of the larvae, royal jelly quality and quantity. $J$. Anim. Vet. Adv, 3: 120-122.

Şahinler, N., Gül, A., Şahin A., 2005. Vitamin E supplement in honeybee colonies to increase cell acceptance rate and royal jelly production. Journal of Apicultural Research, 44(2): 58-60

Şahinler, N., Kaftanoğlu, O., 2005. The effects of season and honeybee (Apis mellifera L.) genotype on acceptance rates and royal jelly production. Turk J Vet Anim Sci., 29:499-503.

Temamoğulları K. F., Aral., F. Demirkol., R., 2006. Erkek farelerde arı sütünün uzun süreli uygulanmasının bazı spermatolojik özellikler üzerine etkisi. Fırat Üniversitesi Veteriner Fak. Dergisi, 20(5): $341-344$.

Uçak Koç, A., Karacaoğlu, M., 2004. Effects of rearing season on the quality of queen honeybees (Apis mellifera L.) raised under the conditions of Aegean region. Mellifera, Türkiye Arıcılık Dergisi, (4)7: 34-37.

Uçak Koç, A., Karacaoğlu, M., 2005. Anadolu arısı Ege ekotipi (Apis mellifera anatoliaca) ana arılarında üreme özellikleri. Adnan Menderes Üniversitesi, Ziraat Fakültesi Dergisi, 2(1):73-77.

Uçak Koç, A., Karacaoğlu, M., 2011. Effects of queen rearing period on reproductive features of Italian (Apis mellifera ligustica), Caucasian (Apis mellifera caucasica), and Aegean ecotype of Anatolian honeybee (Apis mellifera anatoliaca) queens. Turk. J. Vet. Anim. Sci., 35(4): 271-276.

Wytrychowski, M., Chenavas, S., Daniele, G., Casabianca, H., Batteau, M., Guibert, S., Brion, B., 2013. Physico chemical characterisation of French royal jelly: Comparison with commercial royal jellies and royal jellies produced through artificial bee-feeding. Journal of Food Compositionand Analysis, Volume 29(2):126-133

Wang, X., Cook, L. F., Grasso, L. M., Cao, M., Dong, Y., 2015. Royal jelly-mediated prolongevity and stress resistance in caenorhabditiselegans is possibly modulated by the interplays of DAF-16, SIR2.1, HCF-1, and 14-3-3 Proteins. J Gerontol A Biol Sci Med Sci, 70(7): 827-838.

Xin, X. X., Chen, Y., Chen, D., Xiao, F., Parnell, L. D., Zhao, J., Shen, L. R., 2016. Supplementation with major royal-Jelly proteins increases lifespan, feeding and fecundity in drosophila. Journal of Agricultural and Food Chemistry, 64(29): 5803-5812.

Yücel, B. Kösoğlu, M., 2011. Ege Bölgesi'nde Muğla ekotipi ve İtalyan melezi bal arılarının kimi performans özellikleri bakımından karşılaştırılması, Kafkas Univ. Vet. Fak.Derg., 17(6): 1025-1029.

Zheng, H.-Q. Hu, F.-L., Dietemann, V., 2011. Changes in composition of royal jelly harvested at different times: consequences for quality standards, Apidologie, 42: 3947. 